の大い过 $0-1,2-4,5-10,11-20,21-30,31 \mathrm{~mm}$.

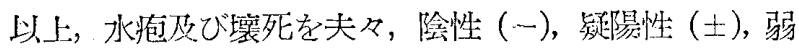
陽性 $(+)$, 中等度隄性 (H), 强陽性 (H), 最强隄性(州),
B不びNとし，48時間後に判定した。

文献

第五報末尾に一括記載する。

From the Third Medical Clinic of Kyoto University

(Director: Professor M. Maekawa M. D.)

\title{
Studies on the Experimental Myocarditis by the Lung-Phosphatide (I)
}

$\mathrm{By}$

\author{
Shukichi TaKagI
}

(Received for Publication, May 25, 1950)

\section{肺臟フォスファティード加牛血清に依る蛪驗的心筋炎に關する研究（第 1 報）

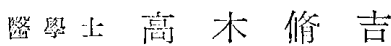

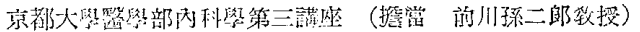

Many works have been already reported, by those which was confirmed MAEKAWA's Idea that the substance which determines allergic affinity must be cell phosphatide. As one of these works I sensitized the rabbits intravenously with a mixture of rabbit-lung-phosphatide and fresh oxen sera. At

\section{筇一音 緒論}

1 フォスファティード亟び其の抗原性

1812 年 Vauguelin ${ }^{1)}$ は人度び敖種の動物の腦の類脂 鳢中心有機的儿結合与る燐の存在を䘞めて確認した。次

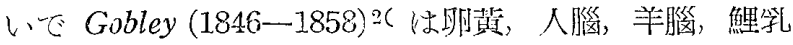

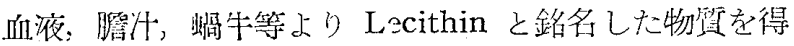
たが，该 Lecithinは㺘不純なもので，其の權造中脂肪 睃とグリセ口燐酸を分们し得たが，空素の結合樣式を確 定するに至らなかつた。續いて Diakonow (1867一1868)

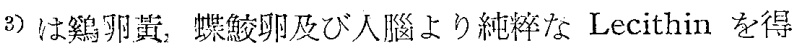

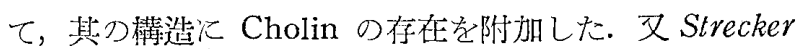
$(1838)^{4)}$. は脂肪酸の椣類に依つて區別され得る數樌の Lecithin の程類の有る事を指摘した. 1874 年 Thudic-

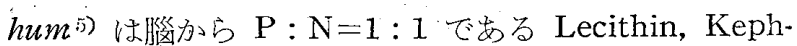
alin, Myelin, Paramyelin を, $\mathrm{P}: \mathrm{N}=1: 2$ でる Sphingomyelin, Amidokephalin, Amidomyelin, Apomyelin を，及び䇪素非含有の Lecithin 類似物質を分 析して，之等を Phosphatide と總稳した。爾夾 Bang $(1907)^{6)}$ Erlandsen (1907)7) Fraenkel (1908) ${ }^{\text {s) Leathes }}$ (1910, Phospholipines) ${ }^{D}$ Cramer (1911) ${ }^{10)}$ Julius Ep. pler (1913) 11) MacLean (1927, Phospholipins) ${ }^{12)}$ Channon \& Chibnall (1927, Diglyceridphosphoric Acid) ${ }^{13}$ ) 等によつて䃊究され，Thierfelder u. Klenk $(1930)^{14)}$ に 從光ば Phosphatideの分類は，'1) Monoamino-monophosphatide (Lecithin, Kephalin) ; 2) Diamino-mono- about three weeks after the sensitization these rabbits were reinjected by the same antigen and then dissected. During the total course of this experiment I examined each organ clinically, serologically and histologically.

phosphatide (Sphyngomyelin); 3) N-freie Phosphatidsaeure ( $\alpha-\mathrm{u}$. $\beta$-Diglycend-Phosphorsaeure) で あつて，其の中 Sphyngomyelin は未だ其の構造に疑問 の點を残している.

フォスファティードが贋く生體の諸践器組織細胞に分

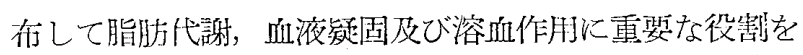

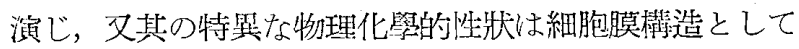

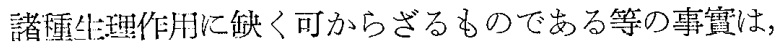
本物澌の個體に於ける意竜を充分ならしめるものである が，就中其の抗原性閵しても多數の注目に筫する業績 が見られる。

1906 年 Bang u. Forssman ${ }^{15}$ ). は牛赤血球から得た

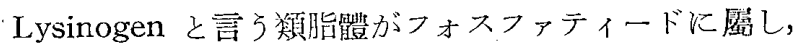
溶血性抗原となり得るとした。 Dauwitz u. Landsteiner $(1907)^{10)}$ ，高木 (1908) ${ }^{17)}$ Schmidt (1922) ${ }^{18)}$ 等は之に賛 成し，Thiele \& Embleton (1913) ${ }^{19)}$ は之に反對して 㔷る. Frouin (1911)20) はエーテル・アセトンで處理 した赤血球ス下ローマは溶血性抗原となり得ないと

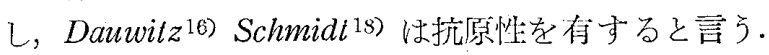
其化 Iwai (1917)年) Wernicke u. Sordelli (1919) 22) b

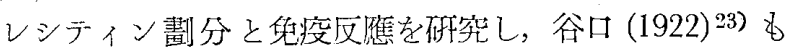

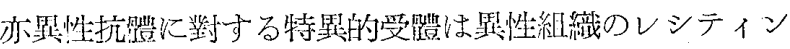
劃分中に存在すると述べた，1923年林村さは牛赤血球 のエーテル。エキスより $\mathrm{P}: \mathrm{N}=1: 2$ の 2 積，及灭び酒精 エ车より $\mathrm{P}: \mathrm{N}=1: 2.5$ の 1 䅜, 尌 3 䅜のフォスファ 
ティードを得て，之等は何れも家束に於て牛赤血球に對 する溶血素を生成する能力を有しないと結論して居る。

1925 年 Sachs u. Klopstock ${ }^{25)}$ は Lecithin, Cholesterin 等に Schleppar として豚血清を添加して家雨に接

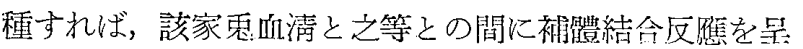
寸る事即ち Hap等 である事を證明し，同年 Heimann 26) は Lecithin に豚血清を添加した場合と，馬血清を添

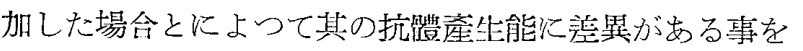

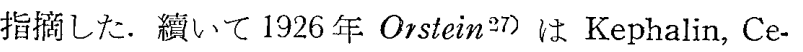
rebrosid, Testislipoid を, 1927 年 Levene, Landsteiner u. Scheer2s) は柯盟Ovolecithin を, 1931 年Weil u. Besser ${ }^{29)}$, 疋 1933 年 Maier ${ }^{30)}$ は合成 Di-Stearyl-Lecithin を用いて，何れも異種血清附加により抗樌を造り

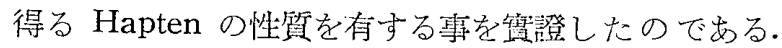
1930 年末吉支び确滕 31 は Lecithin, Cholesterin に浑 猽血清を添加すると Sachs u. Klopstock ${ }^{25)}$ の言う如く 特異性抗體を止じ，又 Lecithin 又は Kephalin と游猽 血淸との混合物による家鬼免疫血清は，各及に特琵的補

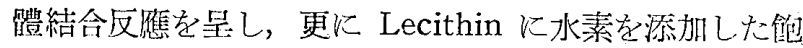
和 Lecithin と及び不飽和 Lecithin と䘮同梌に抗原々

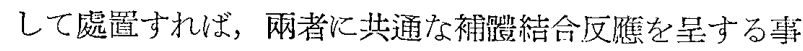
を認めた。同年須藤 32 は方貶 Ovolecithin を更に化學 的に精製したものを以つて諸種の筫驗を行い, Lecithin

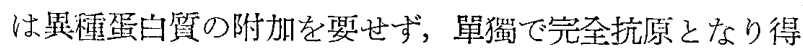
ると言う絬論に達した。

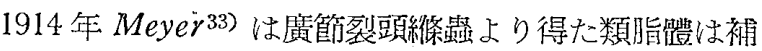
體結合反應を呈し，且其の類脂體中レシティン樣のもの

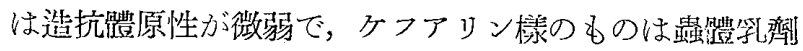
を以つてしたと同程度に抗澧㘱生を認めた。

1930 年.伊藤 は Schlepper と共處置する事によつて特琶性抗澧を

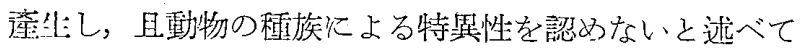
いる.

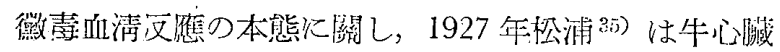
より得な純レシティンは「ワ」氏抗原となり得ず。又動 物武政に於て子陰性であるとし，同年Klopstock ${ }^{2}$ ( は化 學的に合成した Lecithin, Kephalin の抗原性に閵して 䆏殮を行い，Lecithin は充分ではないが，Kephalin は 接種により 10 例の「ワ」氏反應㓌性家乘血清を9例迄 陽轉させ得る事實を報告した. 後 Dudgeon u. MacLean (7) により「ワ」氏反應抗原性を有するものは Lecithin と分離する事の困難な他種の物質である專が栄明せられ た。

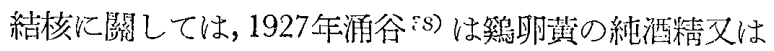
純アセトン浸出物をレシティンで稀釋したものを以つて

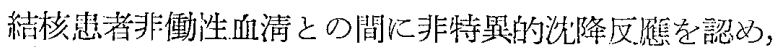
依つて結核应重輕の制別に用儿樣とした。同年 Sabin \& Doan 39) 㕆び 1932 年 Sabin 40) は Anderson (1927-19 29) +1) の結核菌フォスファティード劃分 A-3 (Phihioic acid)，A-4 に就いて組織反㷳を家乘に於て检し，本劃
分が類上皮細胞，ラングハンス氏巨態細胞を形成し，結

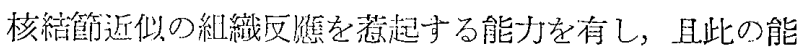

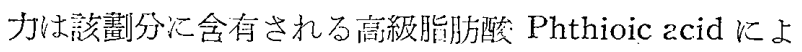
るとし，更に 1932 年 Smithburn ${ }^{42}$ ) と共に瀨菌其の他の 抗酸性菌のフォスファディード劃分にも同樣の組織反焦 を認めると同时て，上記結核困畫分の抗原性關し，該 劃分を以つてしては意外にもッベルクリン反㷳の陽持を

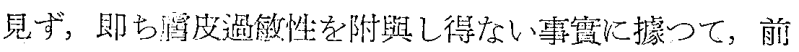

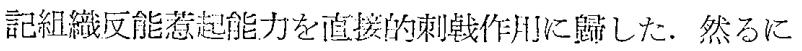

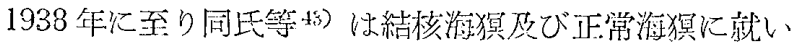
てフォスファティードの作靔を括檢討し，感作例ではコ

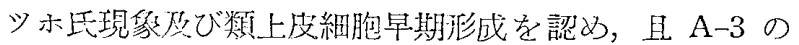

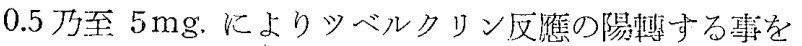

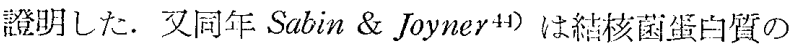
有する感作原监㥙，之にフォスファティード劃分を加之

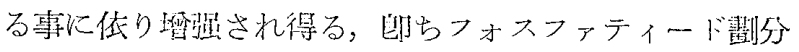

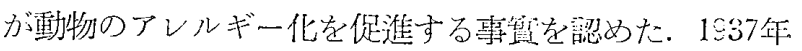
Roulel u. Block t.j は之を近試し Anderson+11) のフ大

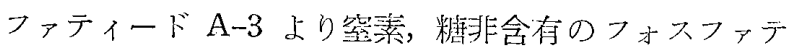

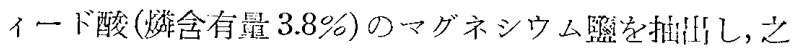
に依つて單なるフォスファティードに供るよりも更に强 度に結核絈節に酷似与る肉芽霾を形成し得て，彼も其 の作用をその㪸成分子である Tuberkulostearinsaeure 互び d-Phthionsaeure に釋し，且此の作攸は結核感染家 鬼と正常家乘の間に美罢がない點及びフォスファティー

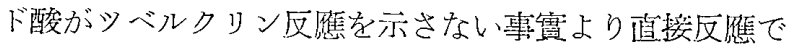

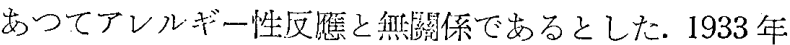

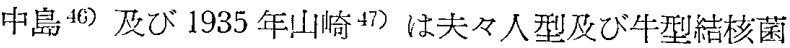
フォスファティード劃分恃共に單獨で造抗原性を有し，

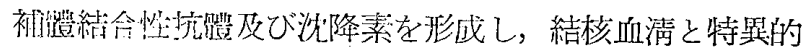

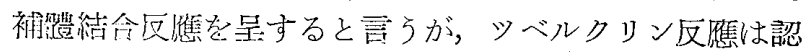
めなかつた。1934 年户田・劄頭等 48) は Anderson 41) に 佔つて得た結核菌フォスファティード劃分は結核アレル ギーの感作元性，反㺘元性を有しないが，一定度の免疫 元性圶有する專から，結核アレルギー相と象疫相の不一

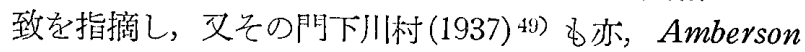
氏法41)によつて得た結核菌フォスファティード劃分 I 及びIIは，海猽のツベルクリン反應を陽獎させ得ない が，此のッベルクリン・アネルギー下に於てはよく結核 菌の體內撒布を退延させ得る能力を有する故に，ツベル クリン・アレルギーと免废の分耀の可能性を暗示するる のとした. 1938 年森 ${ }^{50)}$ も亦，同劃分で感作してもッべ ルクリン反應を旺せず，且組織學的にも脫脂菌反應と差 なく，其の他の劃分反應に比し特に巨態細胞形成子優れ ていると言えず，故に單なる罢物反㺘であるとし，1939

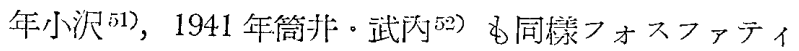
ード A-3 によつてはアレルギー性衡化を認めないとす

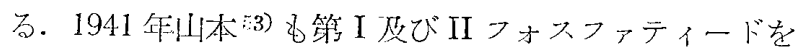

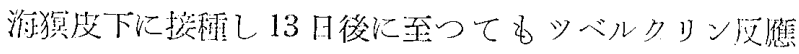

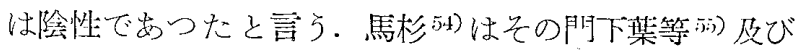




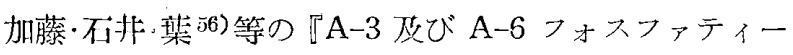
ド频回行胍可注射により類上皮細胞形成は之を認めるが

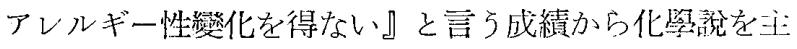

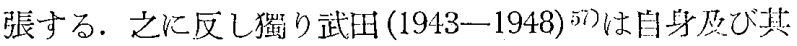
の門下の莱績に立脚して『結核菌フォスファティードに

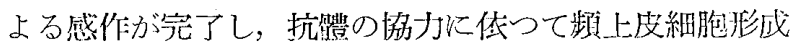
が萑起される』とし、アレルギー證を主張して居る.1947

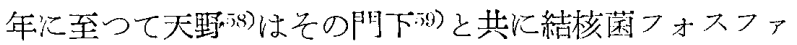
ティード分劃は輕度のッベルクリン反應を示す事を認め

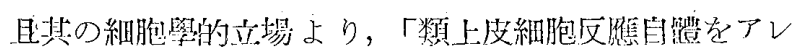

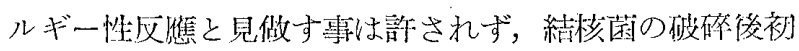
めて分厚への反㕍が化學的に行わ机るので，但し茲にア

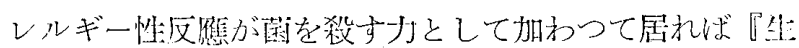

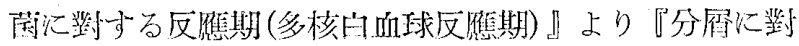

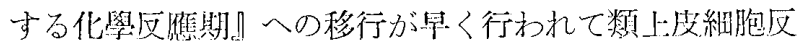

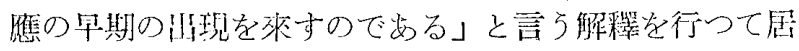
子.

肺炎藏又は䄸清を以つてデレルギー性肺炎を惹起させ た珼噞は数多いが，フォスファティードに閵速したもの

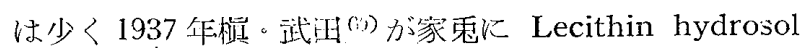

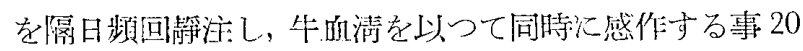
回に㬎べば，Arthus 現像の高度の發現不び心墄冠狀動

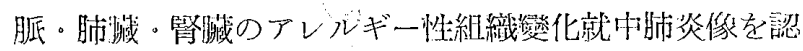

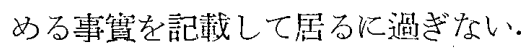

以上楛程の文献を通筧すると1923 年 Landsieiner $u$.

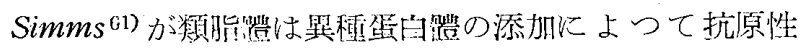
を發揮し得ると言 5 Hapten の概念を樹立して以來，フ オスファティードも文現今迄の處，其れ單㺈では完全抗 原では热いが Hapten として作瑚ると考光るのが正賞 でせろら。

II アレルギーの減器視和州に於けるフォスファティ ードの意義に就て

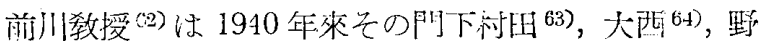

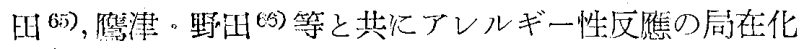

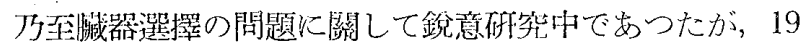
47 年に至り，Lehmann-Facius (1930) 67) の癌腫フォス ファティード劃分と癌㭧者血清との間の特買的䓡狀反㷳 不び中川 (1939)(8)のその追試改良成績に顧み，荒不 ${ }^{699}$ に

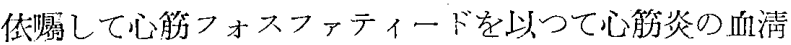
學的耪斷 (Cor-Phosphatid-Reaction, 以下 CPR. と降 す)に成功した．荻野。植野等 70) は該劃分の化學的組成

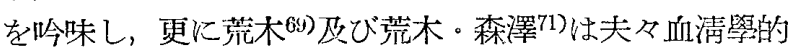

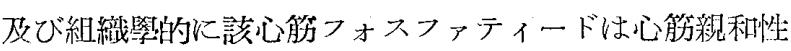
を示すが種屬特樭性を示さない事を證明した。

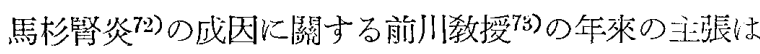
『达74)の說く如き逆アナフィラキシ一現爱に非ずして，

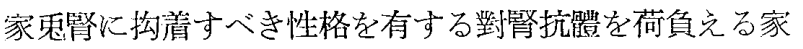
鴨血淸に依りて惹起される正アナフィラキシー抗原抗椹

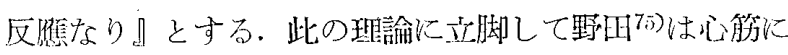
親和性を有する上記心筋フォスファティードを牛血清に

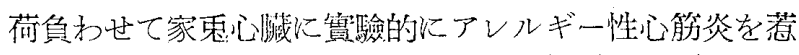

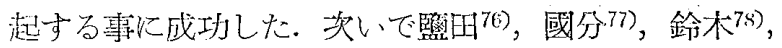
吉出・堸田等793

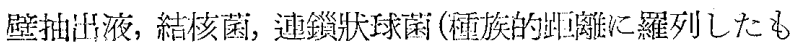
ので，抗原スペクルと晸程する）を以つて何れも家香 にアレルギー性心筋炎を起し得た，又陚內。小川500は本 來心筋に親和性を有するディフテリ一表素㣻びアナトキ シンでさえ心笳フォスファティードを負何する事により

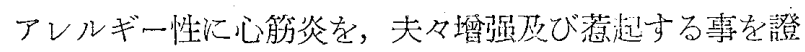
明して屈る。

一万服部 人・牛肩桃腺フォスファティードと牛血清の混命物を以

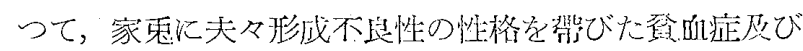
白血球(特に湘巴球)增多をアレルギー性に遁り得た。

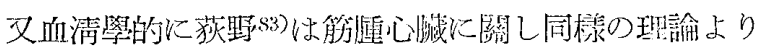

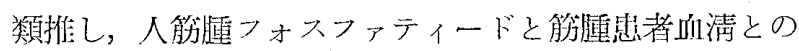

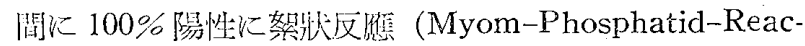
tion, 格 MPR.) を認め，且之と CPR.の間に大なる交

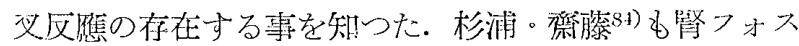

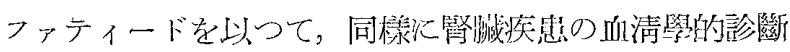
法 (Ren-Phosphatid-Reaction, 略 RPR.) K供せ九と

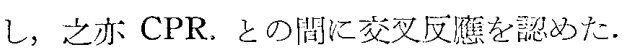

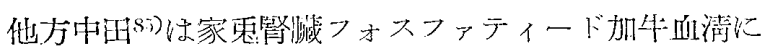

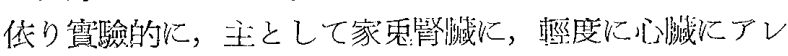
ルギー性炎症を菁起し，其の際高血監を示与例をも證明

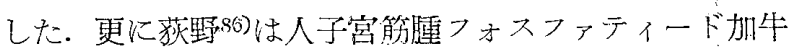
助清を以つて主として心減に輕度の所見を゙得，成㗬。小

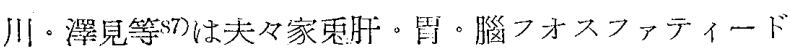
《就き同樣の所見を得ている。

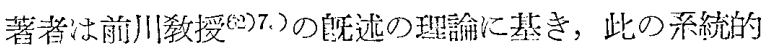

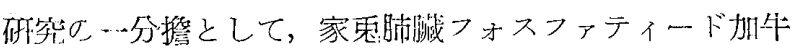

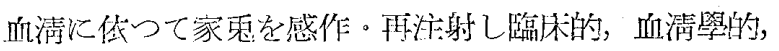
組織學的に所自を得たので其の成續を茲に報告する。

\section{第二章 實驗材料及び實醶方法}

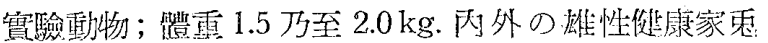

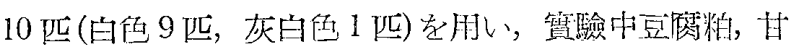
墸慳葉，根荣，青草等の一定量によつて䬲盖した。

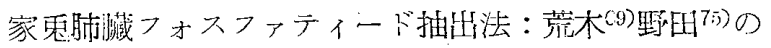
心䈈フォスファティード抽出法に做い，即ち新艎な徒康

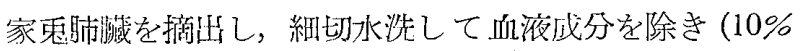
フォルマリン水固定したものも流水中で充㕣水洗し，フ オルマリン完全除去を行光ばよい)，脫脂濾紙に狟み，拭

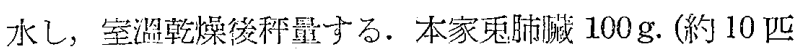
分）を乳銪內で金阙砂を加光細挫し，無水酒精 $500 \mathrm{cc}$. 学

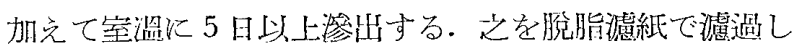

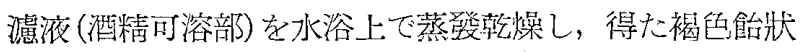
殘渣に約 $300 \mathrm{cc}$. のベンゾールを加えて加温溶解する. 室埧に冷却後同樣濾過し，ベンゾール可溶部を再び水浴

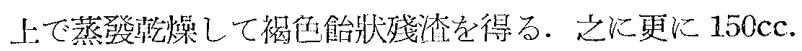
のア七トンを加え，加熱した後公滥に洽却する。この際 
アセトン不溶殘渣は容器壁に附着する故，斜傾してアセ トン可溶部を捨て，殘椬に石油エーテル少量を加えて溶 解し，濾過する，不油エーテルを室溫で蒸發させ，殘渣 を容器と共に科量する. 此の殘渣を無水酒精滴量飞, 加

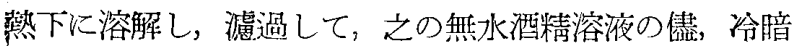
所に保存する.この際比ずる残渣も又，容器壁汇附着し て濾紙上へ移行しない故に, 再び容器と共江科量し, 先 きの石油エーテル蒸發殘渣秤量值との渚を以つて無水酒 精中のフォスファティード量を知る.フォスファティー ド聮水酒精溶液は所要量に分注保存すると便利で，用に

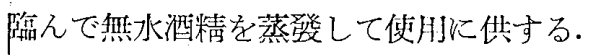

本家乘肺㶓フォスファティード劃分の化學的純度及び それと組織反鷹との關係は今後の呼究に侯たねばならな い.

\section{I 主 實 驗}

1) 本 試 䎏

家鬼 7 匹，No. 321，322，323，324，161，162，163 (全 部白色）肺いた。

抗原：無菌的に㨲取した新鮮牛血清，家雭體重 $1 \mathrm{~kg}$. 當り $2.0 \mathrm{cc}$. に, 前記家鬼肺践フォスファティード $30 \mathrm{mg}$.

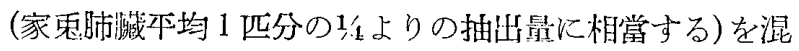
合し，よく振襡してェムルジオンとし, 室溫に 1 時間放

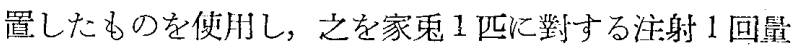
とした.

感作：本抗原を以つて連續 4 日間 4 回，家鬼耳靜脈队 に注射した。

垔注射：感作終了翌日より起算し第 23 日目上り連續 3 日間，3回炕亘り，感作之同一抗原を以つて同じく耳静 胍內涂々に行つた。

剖檢: 家乘 No. 321，322 は再注射後夫及第 3 日，5 日 目K，No. 323，324 は第7 日目に失血致死させて行い， 直ちに心，肺，肝；粲，脾，副腎，腦等を摘出し，10\% フォルマリン水固定，ツェロイディン包埋切片とし， 几 マトキシリン・エオデン重染色法, Van. Gieson 氏染色 法, Weigerl 氏彈力織維染色法等を肞い，病理組織學的 に檢索した。

2) フォスファティード對照試驗

家秋 3 匹，No. 325，164 (以上白色)，165 (灰白色) を 朝いた.

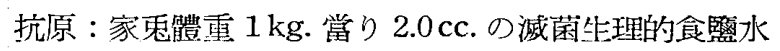
に，家鬼肺臟フォスファティード $30 \mathrm{mg}$.をエムルジオ ンとしたものを使肌した。

感作，再注射，剖檢：再注射後失血致死させるに至る 期間を，家躳 No. 325；164 亿就き，夫久第 5, 7 日目と した以外は全く本試驗と同樣に實施した。

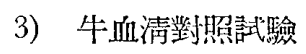

野田可)を公照する事とし，著者の實驗に於ては之を省 略した。

II 䠦床觀察

實䐘動物は全經過中下記譛檢査を實施し，觀察した。
1) 體重科量：動物自動积を用いた。科量時期可數； 感作前 3 回，感作後 2 乃至 3 回，再注射後 1 乃至 2 回， 計 6 乃至 8 回炕科量した.

2）體溫測定：人體體賉测定用 1 分計を用いた。肛閒 冈 $4 \mathrm{~cm}$. の深さに插大, 5 分間測定した. 測定时期回數; 感作前 2 乃至 3 回，感作後 3 回，再注射後 2 乃至 3 回， 荅千 7 万至 9 回.

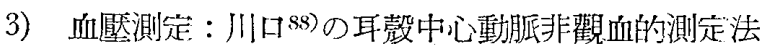
に依つた. Feldberg ${ }^{59)}$ に從い全實驗動物の Ggl. cervicalis sup. の摘出灭び Nn. auriculares dors. et vent. の切斷を行い，耳㲄血管運動种經の影響を除き，術後 1

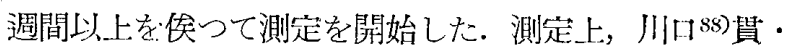
大僑・和田90)の注意を嚴守した. 15 秒間榞 10 回測定の 平均値を探川した。测定時期汇數；感作前後 2 万至 3 回 再注射後 2 回, 部 6 万至 8 回.

4), 呼吸數測定 : 安静狀態の家東沉就いて，其の鼻翼

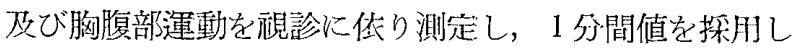
た. 测定時期回數; 感作前 1 回，感作啳 3 回，再注射後 2 乃至 3 回，部 6 乃至 7 回测定.

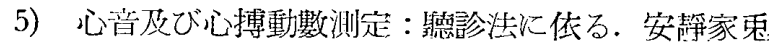
1 分間值を採肘した。測定時期友び回數; 感作就 1 回, 感作後 1 万至 2 回，再注射後同前，塥 3 万至 5 回.

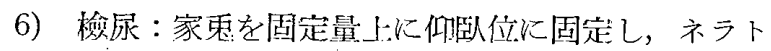
ン・カテーテル2 號を用いて導㲾した膀胱尿に就き，量

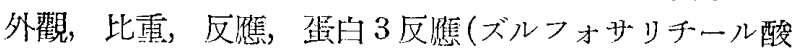

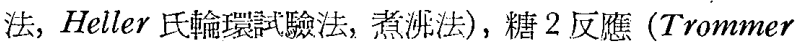
氏法, Almén-Nylander 法法)，ビリルビン(Rosin 氏 沃度丁䇝法), ウロビリン (Schlesinger 氏法), ウロビリ ノーゲン (Ehrlich 氏洁) 並びに沈洫を檢した。檢尿時期 回數; 感们前, 再注射後, 剖檢前各 1 回，感作後 1 万至 2 回, 計 4 万约 5 回.

7）血液檢查：筫驗家鬼耳読未枌靜脈血江就き，赤及 び白血球數，血色素定最(Sahi-小宮氏洗)，白血球百分率 (普通塗抹 Giemsa 染色法), 網狀赤血球數(ブリリィア ント・クレジールブラウ超生體染色法, Giemsa 後染色 法), 血小板數 (Fonio 氏法)を檢した。檢査期; 感作前 後, 再注射後, 剖檢前各 1 回涪十 4 回.

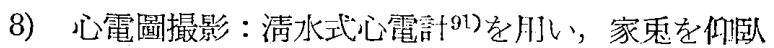
位固定とし，電極を四肢附亘部化適用，技誘導を行つた。

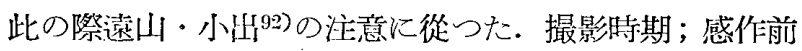
後, 再注射後の 3 回.

9) X線撮影 : 島津式移動型 X線裝置を䏘，家躳は 仰卧位固定に於て初電辟 $80 \mathrm{~V}$., 管流電流 $70 \mathrm{~mA}$., 距離 $150 \mathrm{~cm}$, 露出時間 $20 / 100$ 秒て撮影した. 撮影時期前同.

III Pulmonum-Phosphatid-Reaction (PPR.) 高崎 荻野 - 荒木 ${ }^{(9) 933)}$ の Cor-Phosphatid-Reaction (CPR. \& 略稱) 飞做い，下記反應党 Pulmonum-Phosphatid-Reaction (PPR. と略稱) と銘名する.

家鬼血清「オイグロブリン」液の作製法: 荒木69)の方

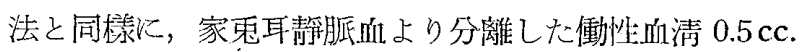


に，10 倍容量の $1 / 250$ 規定鹽酸を㩭汼しつつ加党，30 分 間水室詝藏の後, 這心沈澱し，落した「オイグロブリン」 を，人間對家躳の血清蛋白量の比率を考虑して，生理的 食監水で 2,3,6 倍の 3 種の稀釋液として用いた。

家香肺臟「フォスファティード・エムルジオン」の作

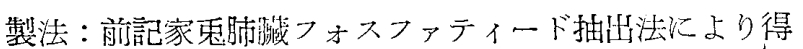
た，無水酒精 $1 \mathrm{cc}$. 中肺臟フォスファディード $2 \mathrm{mg}$. を

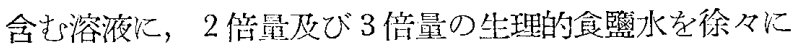

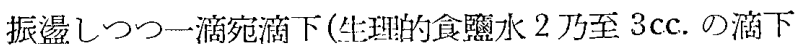
に 15 万至 20 分を費寸程度を至適速度とする）して得た 2 程のエムルジオンを胢いた。作製後 30 分以队使肞す 万.

反隼：上記家鬼「オイグロブリン」㢈 0.2 cc. 在僙底 「スピッッ・グラス」に大れ，之に家乘肺践「フォスファ ディード。エムルジオン」0.4cc. 孝加光, 充分混和した 後, 直ちに 1 分間 3000 回博 5 分間遠心沈澱寸る. 得た沈 澱を輕く叮きつつ管底より遊離させ，凡び同回轉速度で 2 分閻遠心沈搌し，上清を捨て，管壁を扛い，40\%「フ

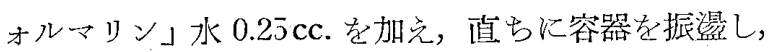
管底の洗澱物が遊離して一見「フォルマリン」水に微細
に分れる程度とする. 其れ以上の振盪は不可である. 其 の際生じる浮遊物の程度により $(+),(\perp),( \pm),($ ) 等 と刵定した。

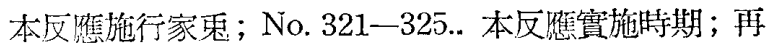
注射前日及び再注射徍失血致死時の 2 回.

\section{Arthus 現家}

感作終了型日より起算し,第 21 日目の全實驗家鬼の鋏 毛した腹部皮內に，下記 3 䟱の抗原液を以つて，夫夕左 右對秷的に 2 万所宛，計 6 万所に注射し，48 時間後に緒 方 ${ }^{94)}$ の判定規準に從い，第 1 度一第 4 度に區分し物定し

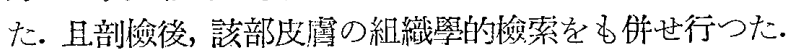

1) 家鬼肺倣フォスファティード $30 \mathrm{mg}$. を, 隇菌生 㻎的食䜿水(家秋體重 $1 \mathrm{~kg}$. 當り $2 \mathrm{cc}$.) にエムルジォンと

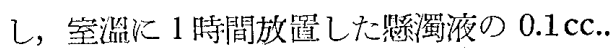

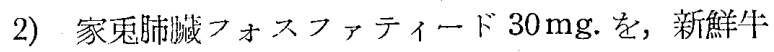
㿼清 (家串體重 $1 \mathrm{~kg}$. 當り $2 \mathrm{cc}$.) にエムルジオンとし，室 㴓に 1 時䦓放惪した子のの0.1 cc..

3) 新鮮牛血清の $0.1 \mathrm{cc}$.. 文献

第 4 報末尾に一括記載する.

From the Nagoya Medical School (Director: Assist. Prof. H. Toyoshima, M. D.)

Some Investigations in the Diaginosis of Origin of Ventricular Premature Beat by Vectorcardiography

$\mathrm{BY}$

KaZUO YAMADA

(Received for Publication,

195)

\section{ベクトル心電圖に依る心室性期外收縮發生點の局所診斷に就いて \\ 山田和生

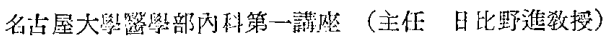

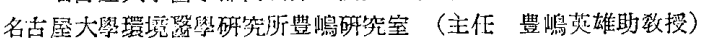

The diagnosis of origin of ventricular premature beat in ECG is not yet unified.

So, I performed the experimental research on the diagnosis of origin of ventricular premature beat by polyography exciting the various points of toad heart with induction stimulator. Points to lead were selected eight point on the ventral surface surrounding the heart with same distance. In some cases the direct unipolar electrocardiograms were led from epicardial and endocardial surface adjacent to stimulated point to compare with the results of VCGs.

1) The polyograms obtained by stimulation of the corresponding epicardial and endocardial surfaces were coincided very well in their forms, directions of long axes, initial and terminal directions and rotation of QRS. loops.
These findings showed that the effect of the electromotive force across the ventricular wall at stimulated point was too small to change the vectorcardiogram. I ascertained also these findings by direct unipolar lead ECGs.

Namely, when I stimulated the epicardial surface and led the unipolar ECG from adjacent point to it, the tracing began with $Q$ wave after 0.01 sec. (mean value) of Iatency.

Stimulated the endocardial surface near the apex and led the unipolar ECG from just above points on epicardial surface the tracing began with $Q$ wave after $0.07 \mathrm{sec}$ (mean value) of latency. On the contrary, stimulated the epicardial surface and led the unipolar ECG from subjacent endocardial surface, the tracing began also with $\mathrm{Q}$ wave after 0.14 sec. (mean value) of latency. Both curves were 